\title{
Consideration on the price stability - financial stability relationship in the context of financial globalization
}

\author{
Marius Constantin Apostoaie, “Alexandru Ioan Cuza” University of Iasi, Romania
}

\begin{abstract}
This study is focused upon the involvement of the central banks regarding the fulfillment of the two main objectives: price stability and financial stability. These two key concepts are part of an old and ongoing debate that the current turmoil has revived, and that is whether monetary policy should aim, or not, at ensuring financial stability in parallel to its main objective of price stability. On both sides there are solid and well known arguments.

In the beginning of the study I have considered a literature review with regard to price and financial stability issues. After that I have tried to shed some light (from a theoretical point of view) on the nature and dynamics of the fundamental interlinkages between the two aspects and there implications on the central banks and the economy. Finally I outline some general conclusions that have emerged in the present study.
\end{abstract}

\section{Key words}

Price stability, financial stability, central banks, monetary policy, primary objective, financial turmoil, financial system, financial globalisation

JEL Code: E58, G01

\section{Introduction}

The unprecedented structural mutations and disruptions in the financial systems of national economies and also the turmoil specific to financial markets today under the impact of financial innovations, require an urgent restoration of the fundamental objective of the monetary policy promoted by the central banks in the area of systemic stability. This action is necessary because the recent international turmoil show that stabilization of inflation at low levels at the same time with economic growth configures a "new economic environment", apparently sound, in which financial stability is not gained collaterally.

A monetary policy promoted by the central banks with an essential role in ensuring financial stability is justified by the double causality relationship between financial stability and monetary policy: on the one hand, a stable and solid financial system allows an efficient transmission of the monetary policy decisions and, on the other hand, the operational framework of an efficient monetary policy may allow the prevention and removal of financial disturbances. At the same time, the occurrence of the present global crisis allows the empirical testing of the hypothesis according to which the stability of prices, as a fundamental objective of the monetary policy, currently stated in the statute of most of the central bank, is a vital condition, but not sufficient in order to ensure financial stability.

\section{Stability of the prices and the financial stability - theoretical approach}

In theory as well as in practice, there is required a delimitation between the two concepts presented in this paper, "stability of the prices" and "financial stability", considering the 
existence of several definitions of the former and the absence of a unanimously accepted definition for the latter.

Nowadays, most important central banks in the world, due to their status, have assumed as the main objective of monetary policy "the ensurance of stability of the prices". Bernanke (2006) considers this objective is a purpose in itself, as well as a tool for the monetary policy, as it has a special contribution to the accomplishment of a sustained economical growth as well as to the macro-economical stability, thus reaching a high degree of social welfare.

Beyond the multiple theoretical structures and the distinct empirical perspectives, there is a consensus on the stability of the prices regarding the following defining elements: the stability of the prices refers to the aggregate level of the prices estimated by indexes and it is reached when money keeps a constant value in time or the speed of decrease in its power is very slow; at the same time, as the BNR Governor Mugur Isarescu said (2008), the notion of monetary stability overlaps the one of stability of the prices.

An operational definition of this concept, the stability of the prices, is given by Allan Greenspan (1996, p.1), former governor of FED, SUA, who says that "the stability of the prices represents the situation when the estimations regarding the general increase or decrease of the prices during a considerable period of time do not have an important influence on the economical or financial behavior". According to this approach, the stability of the prices is reached only when the economical agents do not take into account the expected price raises when they make their business decisions.

Some authors make a correlation between the stability of the prices and the inflationist anticipations, thus offering a quantitative, measurable approach. Paul Volcker (1983, p. 5), former president of the Governors Council - Federal Reserve System, during August 1979 August 1987, defines the stability of the prices as "that situation when the anticipations on the general increase or decrease of prices during a considerable period of time do not have a substantial influence on the financial and economical behavior". Alan Blinder approaches the financial stability in the same view (Blinder, 1994, p.7) and he considers it to be "that situation when the expected changes in the level of the prices is sufficiently reduced and gradual so that it might not be taken into consideration in the decisions made by companies and households".

Mishkin also has a quantitative approach (2000, pp.1-13) when defining the concept of stability of the prices. Hence, a corporative engagement from a central bank towards the stability of the prices is not enough to bring the long-desired credibility. The promoted general objective should be translated into a mere quantitative purpose. In 1998, The European Monetary Institute defined the stability of the prices as "the annual increase of the Consumer Price (CPI) for the euro zone under 2\%”. In May 2003, The Management Board of BCE (BCE, 2001) confirmed the definition of the stability of prices, adding one detail: the Board decided that in order to reach this purpose "it is necessary to maintain the inflation rate close to $2 \%$ on medium term".

Ottmar Issing (Issing, 2000), member of the Central European Bank Board considers that the stability of the prices "refers to a stable level of aggregate prices or to a reduced level of inflation". Another member of the Central European Bank, Luca Papademos (Papademos, 2006, p.1) thinks that" the stability of the prices is defined by that state in economy when the general level of the prices is stable, on strict terms, or when the inflation rate is sufficiently reduced and stable, so that the considerations on the nominal dimension of the transactions is no longer a relevant factor for the economical decisions".

The universal establishment (of some important banks like: European Central Bank, Federal Reserve System, Bank of Japan or the National Bank of Romania) of price stability as a fundamental monetary policy objective is self-sustained from the perspective of its advantages regarding: the improvement of the transparency of relative prices, the decrease of the nominal and real interest rates, the protection of the real value of income and fortunes and the prevention of diverting resources from the productive sphere to useless operations of protection against inflation, so that a sustainable economic growth, a better employment and 
increased welfare on the social level may be reached and stability and social cohesion may be preserved.

As a consequence of the intensification in the process of financial globalization and liberalization of the financial and banking markets, and not lastly of the capacity to innovate the financial industry, there has appeared a challenge for the contemporary economy, namely accomplishing the financial stability. In the absence of a viable and stable financial system, the efficiency of monetary policies on reaching the objective of price stability is limited.

Compared to price stability, a concept considered easy to define and quantify, financial stability is a complex concept (as a result of the complexity and dynamics of the financial system) and does not have, as yet, a generally accepted definition and a synthetic index for evaluation. As Jaime Caruana (2005) mentions, ,in spite of the fact that we benefit from a well-structured frame for the debate over the monetary policiy and its application, our reasoning regarding the financial stability is less advanced". Nevertheless, reaching the financial stability is easier said than done. Some authors prefer to approach the financial stability in the view of "what is not" rather than "what really is" (Poloz, 2006).

The economical literature and practice do not provide a unanimously accepted definition of this concept and it is often defined starting from the opposite notion - "financial instability". According to J. Chant (2003, p.3) financial instability refers to "the conditions on the financial markets which affect or threaten to affect the economical performances due to their impact on the financial system”. Similarly, A. Crockett (1997a, p.7) defines „financial stability" as ,the absence of instability", namely, ,the situation when the economical performance is not potentially affected by the fluctuation of asset prices or the impossibility of the financial institutions to fulfill their obligations". It makes the difference between the financial stability regarding the financial-banking institutions and the financial stability of the markets (Crockett, 1997b).

The American economist Frederick Mishkin (1999, p.7) is on the opposite side and he considers that "financial instability appears when the shocks from the financial system interfere with the informational flow in such a way that the financial system is no longer capable of fulfilling its functions and make use of the resources in the most productive activities". William A. Allen and Geoffrey Wood (2006) assert that for the definition of financial stability there is required a definition of the characteristics presented by a "period of financial instability".

In order to understand this notion, Frederick Mishkin (January 2009) refers to two types of risks: the valuation risk and the macroeconomic risk. The first one manifests when the market experiences difficulties in the evaluation process of the complex structured financial products, which lack transparency. The second one appears when an undermining of financing leads to a significant deterioration in the real economy due to the contagion effect (especially at the level of production and of employment).

Ottmar Issing (2003) thinks that it is important to make a distinction between the definition of the financial stability in the view of the system approach and the perspective regarding the volatility of financial variables which are directly noticeable. In this context, the degree of involvement of the central banks could vary according to the need to maintain financial stability.

The literature in the field presents an approach in the wide and the narrow meaning of the concept of "financial stability". Thus, financial stability from a wide perspective refers to the situation when "the financial system can ensure the efficient use of savings for investment opportunities and can face the shocks without major disturbance". But a higher use is presented by the narrow approach of the financial stability which could be defined as "the situation characterized by the absence of banking crises and the presence of a certain level of stability in the asset prices, including the interest rates" (Isărescu, 2006).

The European Central Bank (ECB, 2009) defines financial stability as "a condition in which the financial system - comprising of financial intermediaries, markets and market infrastructures - is capable of withstanding shocks and the unraveling of financial 
imbalances, thereby mitigating the likelihood of disruptions in the financial intermediation process which are severe enough to significantly impair the allocation of savings to profitable investment opportunities".

One of the ex officials of the Federal Reserve System, Frederick Mishkin (1999), considers that financial instability "occurs when shocks to the financial system interfere with information flows so that the financial system can no longer do its job of channeling funds to those with productive investment opportunities".

In the view of the Central Bank of Japan (BIS, 2009), the stability of the financial system points to that situation when the financial system and its participants functions adequately, as well as the fact that the population and the companies trust the system. In order to contribute to the stability of the financial system, the Central Bank makes on-site examinations and offsite monitoring and acts in the quality of lender in order to supply cash when needed.

According to the officials of the National Bank of Rumania (NBR, 2006), financial stability is ,that feature of the financial system that deals with systemic shocks on a sustainable basis and without major disruptions, that allocates financial resources efficiently in the economy and that identifies and manages effectively the risks".

Although the visions of the monetary authorities in what concerns the concept under examination are slightly different, they have a common feature and namely: the ability of the financial system (from the perspective of its constituent elements: the financial markets, the financial institutions, the financial structures, etc.) to efficiently and sustainably fulfill its defining functions both in normal conditions and in periods with disturbances at the level of the economy (macroeconomic shocks)..

In conclusion, the financial stability could be defined as the ability of the financial system to dampen the financial shocks from the inside or outside (at micro- and macro-economical level), after some extraordinary, significant and unpredicted events, accomplishing the economical performance.

\section{Stability of prices $v$. financial stability in relation to the central banks}

Recent events have brought into discussion the dilemma according to which the monetary policy should or should not main objective the insurance of financial stability in parallel to the fundamental objective, namely the insurance of price stability. The arguments brought by both sides, even though contradictory, are strong enough.

In the last two decades, the financial crises manifested in the financial globalization process have determined increased debates between the authorities and in the industry literature regarding the link between price stability and financial stability, giving rise to two essential approaches, the conventional approach and the new environment hypothesis.

The conventional approach to the link between price stability and financial stability was highlighted by the American monetarist Anna Schwartz, who advocated that a monetary policy oriented towards ensuring price stability contributes to reducing the frequency and the negative consequences of financial crises. Such an approach, known in the industry literature as the Schwartz hypothesis claims that price stability is a necessary and sufficient condition for preserving financial stability. (Mésonnier, 2004).

The conventional vision is analyzed based on statistic data, especially in the works of Bordo, Dueker and Wheelock $(1998,2001)$, who highlighted that the most serious banking crises occurred during periods with significant price instability. The studies undertaken by Bordo and others (2001) show, based on statistics and the example of the USA and UK, that there is a significant positive relationship between inflation and financial instability, for the period 1790-1933 and 1972-1999. The conclusion that can be drawn from the works of the previously mentioned authors is that price stability and financial stability are complementary and coherent.

The international financial imbalances occurred starting with 1997 took place in the context of an economic environment characterized by stable prices, which invalidates the 
conventional approach according to which price stability is a sufficient condition for ensuring financial stability.

The study undertaken by Goodfriend (2001) shows for the first time the role of a credible monetary policy (that acts against inflation) in the manifestation of financial imbalances. This vision is also supported in the studies made by Borio and Lowe (2002) and by Borio and others (2003), which show that financial imbalances may occur and, moreover, multiply in a new economic environment characterized by stable prices. These authors show the core role played by a credible monetary policy in the worsening of financial imbalances, explicitly introducing the hypothesis of the "credibility paradox" of the monetary policy.

The "credibility paradox" of the monetary policy or the "new environment" hypothesis highlights the fact that an economic environment characterized by low and stable inflation may create a climate of exaggerated confidence, that would encourage taking considerable risks and, in this context, an excessive rise of the price of financial assets would occur, leading to an instability of the entire financial system.

Herrero Alicia and Pedro del Río (2003) study the main factors of influence which have an impact on the financial stability, with an accent on the design of monetary policy. Their study, made on a sample of 79 countries during 1970-2000, aims to evaluate the fundamental objective of the central bank and the strategy of monetary police which affects the financial stability (in the appearance of banking crises). Thus, we notice the fact that in the case the fundamental objective of monetary policy aims to ensure the stability of the prices, then the possibility to appear a banking crisis is reduced. As regards the strategy of monetary policy, focussing on the currency exchange reduces significantly the probability to appear a banking crises especially in the case of countries under transition.

The empirical studies made by Q. Farooq Akram and Øyvind Eitrheim (2008) demonstrate the fact that the central banks can promote financial stability by stopping inflation and output and that an additional stabilization in asset prices and loan expansion could support the financial stability. The studies are based on the econometric model of the Norwegian economy.

Some authors (Dupor, 2002, p.99-106) consider the possibility of reaching a potential compromise between the stability of prices and the financial stability. The stability of prices is presently considered the optimum target to reduce the improper use of resources in the production sector. Nevertheless, this aspect applies only in the absence of asset price shocks. In case such a shock appears, the stabilization of prices reduces the distorsions which might affect the investment decisions.

The economists Dell'Ariccia and others (2004), in their works, refer to the influence of the banking crises on the loan market and the level of economic increase with a special impact on the financial stability. Thus, they reached the conclusion that adverse shocks lead to weak economic performance as well as tension in the banking environment, while there is a supplementary pressure from the banking sector on the level of economic growth, asthe banks are forced to reduce the level of loans.

Although the literature in the field presents different studies regarding the influence of the monetary policy on the financial stability, the decision factors cannot elaborate precise regulations in monetary policiy, but rather general considerations and warnings which could be used to influence activity. Hence, Lorenzo Bini Smaghi (2008) discusses in one of his papers four general directions the central banks should consider starting from the following issues: the monetary policy in itself could have negative effects on the financial stability; it is very difficult for a central bank to take into consideration the characteristiccs of the financial stability process (especially regarding the waves of the asset prices) in order to accomplish its aims; a monetary policy which neglects the possible problems of financial stability could be inconsistent in time; when financial stability is in danger, the economical and financial indexes could affect the efficiency of the monetary policy.

The present international financial crisis which began in August 2007 on the market of mortgage loans in USA highlights the fact that there might be situations in which reaching 
financial stability is more important than maintaing price stability. In this case, the monetary policy oriented towards price stability could accept, at least on short term, (usually 2 years) the adoption of priority measures so as to ensure the financial stability. In its absence there could not be reached an increase in the efficiency of the monetary policy and consequently the stability of the prices on medium and long term.

We must take into consideration the fact that the trend of the monetary policy has influence on the profits on the financial market. Therefore, the connection between the monetary policy and the price of the assets is debated in the literature in the field and different empirical studies (Sellin, 2001).

\section{Conclusions}

Analysing the relationship between the monetary stability and the financial stability, we could assert that there is a two-way connection between the two. Even though the fundamental objective, on long term of a central bank is generally to ensure the stability of prices, there should be paid particular attention to the financial stability. Otherwise, even though there is made progress in the decrease of inflation, their sustainability is not encouraged in the context of an unstable financial system. The impossibility to maintain the financial stability can only lead to a reburst of inflation.

According to the analysed materials, under the present day macro-economical context, at the level of the monetary policy objectives, the central banks are naturally in favour of widening the spectrum from the stability of prices to the stability of the whole financial system, beacuse its solidity at least on short term ensures the premises for the objectives expressed on medium and long term, a conclusion which derives from the studies of the above mentioned economists. Ensuring the financial stability is a normal preoccupation of the central banks which results from their specific tasks. The Bank of England has already included in its legal status the fundamental objective of monetary policy to "protect and consolidate the stability of the financial system of the United Kingdom".

From the point of view of the monetary policy, according to the different views held by the economists we mentioned, the increasing interest of the central banks to ensure the financial stability is explained by the fact that a stable and strong financial system contributes to the increase in efficiency of the monetary policy and consequently to the fundamental objective of ensuring the stability of prices.

\section{Bibliography}

1 Bernanke, B. (2006), The Benefits of Price Stability, speech held at „The Center for Economic Policy Studies" on the occasion "Seventy-Fifth Anniversary of the Woodrow Wilson School of Public and International Affairs", Princeton University, New Jersey

2 Blinder, A. (1994), „Interview with Alan Blinder”, Review of The Federal Reserve Bank of Minneapolis, Available at http://www.minneapolisfed.org/pubs/region/94-12/int9412.cfm, p. 7

3 Bordo, Michael D., Dueker, Michael J., Wheelock, David C. (2001), Aggregate Price Shocks and Financial Instability: A Historical Analysis, Working Paper No. 2000-005B, September, Federal Reserve Bank of St. Louis, Available at http://research.stlouisfed.org/ Accessed 2 Mar. 2010

4 Bordo, Michael D., Dueker, Michael J., Wheelock, David C. (2001), Aggregate price shocks and financial stability: The United Kingdom 1796-1999, Working Paper 8583, National Bureau of Economic Research, Available at http://www.nber.org/ Accessed 3 Mar. 2010

5 Bordo, Michael D., Wheelock, David C. (1998), Price Stability and Financial Stability: The Historical Record, Journal Review, Federal Reserve Bank of St. Louis, September 1998, pp.41-62, Available at http://ideas.repec.org Accessed 2 Mar. 2010

6 Borio, Claudio, English, William and Filardo, Andrew (2003), A tale of two perspectives: old or new challenges for monetary policy?, BIS Working Papers No 127, Bank of International Settlements, February 2003, http://www.bis.org/ Accessed 5.10.2009 
7 Borio, Claudio, Lowe, Philip (2002), Assessing the risk of banking crises, BIS Quarterly Review, Bank of International Settlements, December 2002, Available at http://www.bis.org/ Accessed 25 Feb. 2010

8 Borio, Claudio, Philip, Lowe (2002), Asset prices, financial and monetary stability: exploring the nexus, BIS Working Papers No. 114, Bank of International Settlements, July 2002, Available at http://www.bis.org/ Accessed 3 Mar. 2010

9 Caruana, Jaime (2005), Basel II - back to the future, speech held on the occasion of „The 7th HKMA Distinguished Lecture", Hong Kong, $4^{\text {th }}$ February 2005

10 Chant, J. (2003), Essay of financial stability, Technical report No.95, Bank of Canada, September 2003, Available at http:/www.banqueducanada.ca/en/res/tr/2003/tr95.pdf\#page=19, Accessed 3 Mar. 2010, p.3

11 Crockett, A. (1997a), The Theory and Practice of Financial Stability, GEI Newsletter, No. 6, p. 7

12 Crockett, A. (1997b), Why Is Financial Stability a Goal of Public Policy?, „Maintaining Financial Stability in a Global Economy", symposium held with the support of the Federal Reserve System of Kansas

13 Dell'Ariccia, Giovanni, Detragiache, Enrica, Rajan and Raghuram (2004), The Real Effect of Banking Crises, IMF Working Papers, International Monetary Fund, Washington DC, October 2004, Available at http://www.imf.org Accessed 6.10.2009

14 Dupor, W. (2002), Comment on Monetary policy and Asset Prices, Journal of Monetary Economics 49, p. $99-106$

15 Farooq, Akram Q., Eitrheim, Øyvind (2008), Flexible inflation targeting and financial stability: Is it enough to stabilize inflation and output?, Journal of Banking \& Finance 32, pp. 1242-1254, Available at www.sciencedirect.com Accessed 1 Mar. 2010

16 Goodfriend, Marvin (2001), Financial stability, deflation and monetary policy, Working Papers No 01-01, Federal Reserve Bank of Richmond, Available at http.www.richmondfed.org Accessed 15 Mar. 2010

17 Greenspan, A. (1996), speech held on the symposium Achieving Price Stability, „The Federal Reserve Bank of Kansas City Symposium Proceedings", Kansas City, p.1

18 Herrero, Alicia García, Río, Pedro del (2003), Financial Stability and the Design of Monetary Policy, Documento de Trabajo, No. 0315, Banco de España, Madrid, pp. 14-27

19 Isărescu, Mugur C. (2006), Stabilitatea prețurilor şi stabilitatea financiară, disertation held on the occasion of awarding the title of Doctor Honoris Causa from the University of Piteşti, Available at http://www.bnr.ro/, Accessed 17 Mar. 2010

20 Isărescu, Mugur C. (2008), Probleme ale politicii monetare într-o țară emergentă. Cazul României, Banca Națională a României, Available at http://www.bnro.ro/ Accessed 15 Mar. 2010

21 Issing, Ottmar (2000), Why price stability?, European Central Banking Conference, 2 nov. 2000, Frankfurt am Main, Available at www.ecb.int/events/pdf/conferences/wps issing.pdf

22 Issing, Ottmar (2003), Monetary and financial stability: Is there a trade-off?, BIS Paper no. $18 / 2003$, p. 16

23 Mésonnier, Jean-Stéphane (2004), Le paradoxe de la crédibilité en question, Bulletin de la Banque de France nr. 122, February 2004, Available at http://www.banque-france.fr Accessed 12 Mar. 2010

24 Mishkin Frederic S. (1999), The Causes and Propagation of Financial Instability: Lessons for policy makers, in Global Financial Instability: Framework, Events, Issues, Journal of Economic Perspectives, No. 13, p.7

25 Mishkin, Frederic S. (2000), What should central banks do?, Federal Reserve Bank of St Louis Review, No. 82, pp. 1-13

26 Mishkin, Frederic S. (2009), Is Monetary Policy Effective during Financial Crises?, NBER Working Paper Series, No. 14678, National Bureau of Economic Research, January 2009, Available at http://www.nber.org/ Accessed 10 Mar. 2010

27 Mishkin, Frederic S. (2009), Monetary policy flexibility, risk management, and financial disruptions, Journal of Asian Economics, 29 iulie 2009, (pp. 1-5), Available at www.sciencedirect.com Accessed 2.10.2009

28 Noyer, Christian (2008), La conduite de la politique monétaire en période de tensions financières, Discours, European Banking and Financial Forum, Prague, $1^{\text {er }}$ avril 2008, Available at http://www.banque-france.fr Accessed 27 Feb. 2010

29 Papademos, Luca (2006), Price Stability, Financial Stability and Efficiency, and Monetary Policy, held at the third conference „Monetary Stability Foundation on Challenges to the financial system- 
ageing and low growth", Frankfurt am Main, BIS Review No. 64, Available at www.bis.org/review/r060714d.pdf, Accessed 12 Mar. 2010, p.1

30 Poloz, Stephen S. (2006), Financial stability: A worthy goal, but how feasible?, Journal of Banking \& Finance 30, pp. 3423-3427, Available at www.sciencedirect.com

31 Sellin, P. (2001), Monetary Policy and the Stock Market: Theory and Empirical Evidence, Journal of Economic Surveys, Vol. 15, 2001, pp. 491-541, Available at http://www.sciencedirect.com Accessed 16 Mar. 2010

32 Smaghi, Lorenzo Bini (2008), Financial stability and monetary policy - challenges in the current turmoil, Speech on the EU-US financial system, New York, 4 April 2008, Available at http://www.sciencedirect.com Accessed 17 Feb. 2010

33 William, Allen, Geoffrey, Wood (2006), Defining and achieving financial stability, Journal of Financial Stability, 2, pp. 152-172, Available at http://www.sciencedirect.com Accessed 6 Mar. 2010

34 *** Financial Stability Review, June 2009 (2009), European Central Bank, 2009, p. 9, Available at http://www.ecb.org Accessed 26 Feb. 2010

35 *** International banking and financial market developments (2009), Bank of International Settlements, June 2009, Available at http://www.bis.org/ Accessed 5.10.2009

$36 * * *$ Raport asupra stabilității financiare (2006), National Bank of Romania, pp. 5-17, Available at http://www.bnro.ro Accessed 26 Feb. 2010

37 *** Global Financial Stability Report, Responding to the Financial Crisis, and Measuring Systemic Risks (2009), April, International Monetary Fund, Washington DC, Available at http://www.imf.org Accessed 26 Feb. 2010 